\title{
HUBUNGAN AKTIFITAS FISIK DENGAN KEKUATAN TULANG PADA PASIEN MENOPAUSE DI RUMAH SAKIT OLAHRAGA NASIONAL KEMENPORA TAHUN 2017
}

\author{
Laras Bani Waseso ${ }^{1}$, Basuki Supartono ${ }^{2}$, Cut Fauziah $^{3}$ \\ ${ }^{1}$ Program Studi Sarjana Kedokteran, FK UPN "Veteran" Jakarta \\ ${ }^{2}$ Departemen Orthopedi, FK UPN "Veteran" Jakarta \\ ${ }^{3}$ Departemen Biologi, FK UPN "Veteran" Jakarta \\ Jl. RS Fatmawati, Pondok Labu, Jakarta Selatan 12450, Telp. (021) 7656971 \\ Surel : larasbaniwaseso179@gmail.com
}

\begin{abstract}
Osteoporosis is three times more likely to occur in patients experiencing menopause with low physical activity, resulting in reduced bone mass. The standard examination of bone osteoporosis is an examination of bone mass, also known as BMD (Bone Mass Densitometry). This study aims to identify the correlation between physical activity and bone mass in menopausal patients. This is an analytical observation research that uses cross sectional model. The sample consists of 74 patients from the Kemenpora National Hospital in 2017. Data were analyzed using the chi-square method. The result shows that $37 \%$ of patients with low physical activity had normal bone strength, $63 \%$ had osteopenia and $20 \%$ of patients had osteoporosis. Meanwhile, $52 \%$ of patients with moderate physical activity had normal bone strength, 19\% had osteopenia, and 33\% of these patients have osteoporosis. 16\% of patients with high physical activity have normal bone strength, $18 \%$ of patients experience osteopenia, and $47 \%$ of patients experience osteoporosis. This study proves that there is a relationship between physical activity and bone strength in menopausal patients $(\mathrm{p}=0.004)$.
\end{abstract}

\begin{abstract}
ABSTRAK
Osteoporosis tiga kali lebih mungkin terjadi pada pasien yang mengalami menopause dengan aktivitas fisik rendah yang mengakibatkan massa tulang berkurang.Pemeriksaan standar osteoporosis tulang adalah pemeriksaan massa tulang atau juga dikenal sebagai BMD (Bone Mass Densitometry). Penelitian ini bertujuan untuk mengidentifikasi korelasi antara aktivitas fisik dan tulang massa pada pasien menopause. Ini adalah suatu analitis pengamatan riset yang menggunakan model cross sectional. Sampel terdiri dari 74 pasien dari Rumah Sakit Nasional Kemenpora pada tahun 2017. Data dianalisis dengan menggunakan metode chi-square. Hasil menunjukkan bahwa 37\% pasien aktivitas fisik rendah mempunyai kekuatan tulang yang normal, 63\% yang mengalami osteopenia dan 20\% pasien mengalami osteoporosis. Sementara itu, 52\% pasien aktivitas fisik menengah tersebut masih mempunyai kekuatan tulang yang normal, 19\% mengalami osteopenia, dan 33\% dari para pasien tersebut mengalami osteoporosis. $16 \%$ pasien dengan aktivitas fisik tinggi mempunyai kekuatan tulang yang normal, 18\% dari pasien mengalami osteopenia, dan 47\% dari pasien mengalami osteoporosis. Penelitian ini membuktikan bahwa ada hubungan antara aktivitas fisik dan kekuatan tulang pada pasien menopause $(p=0,004)$.
\end{abstract}

Kata kunci: Physical Activity, Bone Mass Densitometry, Menopausal Women

\section{PENDAHULUAN \\ Latar Belakang}

Osteoporosis merupakan salah satu penyakit degeneratif. Osteoporosis dapat dijumpai diseluruh dunia dan sampai saat ini masih merupakan masalah dalam kesehatan masyarakat terutama di negara berkembang. Di Amerika Serikat, osteoporosis menyerang 20-25 juta penduduk, 1 diantara 2-3 wanita post-menopause (Departemen Kesehatan, Pemerintah Indonesia, 2015).m

Saat ini, Indonesia memiliki jumlah penduduk yang mencapai 237 juta penduduk. Diperkirakan pada tahun $2050,28,7 \%$ pria dan 32,3\% wanita di diagnosis menderita osteoporosis (IOF, 2009). Secara keseluruhan proporsi risiko osteoporosis di tiga provinsi sebesar 22,3\% dan osteopenia sebesar 32,3\%. Proporsi terlihat paling tinggi di provinsi Sulawesi Utara (27,7\%), kemudian Jawa Barat (22,2\%), dan Yogyakarta (17,1\%) (Prihartini, 2010). 
Osteoporosis tiga kali lebih sering terjadi pada wanita dari pada pria. Wanita memiliki massa tulang puncak yang lebih rendah dan disebabkan oleh perubahan hormonal yang terjadi pada massa menopause (WHO, 2003). Pada wanita disebabkan oleh hormon estrogen, semakin meningkatnya umur semakin sedikit hormon estrogen yang dihasilkan, maka akan lebih cepat mengalami kehilangan massa tulang yang lama kelamaan dapat menyebabkan osteoporosis (Ganong, 2008).

Faktor risiko osteoporosis diantaranya adalah aktifitas fisik. Jika aktifitas fisik kurang dapat menyebabkan kepadatan massa tulang akan berkurang (Indonesia, 2015). Klasifikasi aktifitas fisik terdiri dari: aktifitas fisik berat (misalnya mengangkat barang berat, lari cepat, dll), aktifitas fisik sedang (misalnya menyapu, mengepel, dll), dan selain kedua aktifitas fisik tersebut termasuk dalam aktifitas ringan (WHO, 2015). Di Indonesia terdapat 22 provinsi yang penduduknya memiliki aktifitas fisik yang ringan. Lima provinsi tertinggi yang penduduknya memiliki aktifitas fisik yang ringan adalah DKI Jakarta (44,2\%), Papua (38,9\%), Papua Barat (37,8\%), Sulawesi Tenggara (37,2\%) dan Aceh (37,2\%) (Departemen Kesehatan, Kementrian Kesehatan Nasional, 2015). Gold standar menurut WHO 2003, untuk mendiagnosa pasien osteoporosis yaitu diantaranya dengan pemeriksaan BMD (Bone Mass Densitometry)

\section{METODE PENELITIAN Desain Penelitian}

Penelitian ini menggunakan desain penelitian analitik observasional yang bertujuan untuk mengetahui hubungan antar variabel dengan pengujian hipotesa. Penelitian ini menggunakan pendekatan cross sectional, yaitu data yang diambil dan diolah pada waktu yang bersamaan untuk menganalisa adanya hubungan variabel bebas dan terikat (Swarjana, 2016).

\section{Populasi dan Sampel}

Populasi dalam penelitian ini adalah seluruh pasien menopause di Rumah Sakit Olahraga Nasional Kemenpora. Sampel dalam penelitian adalah pasien menopause di Rumah Sakit Olahraga Nasional Kemenpora yang memenuhi kriteria sebanyak 74 orang. Kriteria inklusi dalam penelitian ini adalah pasien menopause dengan rekam medis lengkap dan bersedia mengikuti penelitian. Adapun kriteria eksklusi dalam penelitian ini adalah pasien menopause dengan penggunaan kortikosteroid dalam jangka waktu lama (lebih dari 2 minggu).

\section{Pengambilan Sampel}

Dalam penelitian ini pengambilan sampel menggunakan non probability sampling dengan metode sampling total. Sampling total ialah cara pengambilan sampel apabila semua anggota populasi digunakan sebagai sampel. Hal ini sering dilakukan bila jumlah populasi relatif sedikit, kurang dari 30 orang, atau penelitian yang ingin membuat generalisasi dengan kesalahan yang sangat kecil (Sugiyono, 2009).

\section{Pengumpulan Data}

Data yang digunakan dalam penelitian ini merupakan data primer berupa kuesioner dan data sekunder berupa rekam medis yang meliputi hasil pemeriksaan BMD. Kuesioner yang digunakan dalam penelitian merupakan kuesioner singkat mengenai aktifitas fisik sehari-hari menurut WHO 2015 yang terdiri atas 16 pertanyaan.

\section{Prosedur Penelitian}

Responden sebanyak 74 orang. Peneliti mencatat rekam medis hasil pemeriksaan BMD. Setelah itu, peneliti akan menghubungi responden, menemui responden, dan memberikan informed 
consent pada wanita menopause mengenai aktifitas sehari-hari. Peneliti akan meminta responden mengisi kuesioner aktifitas fisik.

\section{HASIL DAN PEMBAHASAN \\ Karakteristik Responden}

Karakteristik responden berdasarkan usia pasien di Poli Orthopedi Rumah Sakit Olahraga Nasional (RSON) Kemenpora tahun 2017 sebagian besar adalah berusia 51-60 tahun dengan jumlah sebanyak 39 (53\%) pasien. Berdasarkan aktifitas fisik pasien di Poli Orthopedi Rumah Sakit Olahraga Nasional (RSON) Kemenpora pada tahun 2017 sebagian besar adalah aktifitas fisik ringan dengan jumlah sebanyak 33 (45\%) pasien. Berdasarkan kekuatan tulang pasien di Poli Orthopedi Rumah Sakit Olahraga Nasional (RSON) Kemenpora pada tahun 2017 sebagian besar adalah kekuatan tulang dengan hasil BMD osteopenia dengan jumlah sebanyak 32 (43\%) pasien. Distribusi karakteristik responden dapat dilihat pada Tabel 1.

Tabel 1. Distribusi Karakteristik Responden di Poli Orthophedi Rumah Sakit Olahraga Nasional (RSON) Kemenpora tahun 2017

\begin{tabular}{|c|c|c|}
\hline & Frekuensi (n) & Presentase $(\%)$ \\
\hline \multicolumn{3}{|l|}{ Usia } \\
\hline$<50$ tahun & 11 & $15 \%$ \\
\hline $51-60$ tahun & 39 & $53 \%$ \\
\hline$>60$ tahun & 24 & $30 \%$ \\
\hline \multicolumn{3}{|l|}{ Aktifitas Fisik } \\
\hline Ringan & 33 & $45 \%$ \\
\hline Sedang & 25 & $34 \%$ \\
\hline Berat & 16 & $21 \%$ \\
\hline \multicolumn{3}{|c|}{ Kekuatan Tulang } \\
\hline Normal & 27 & $37 \%$ \\
\hline Osteopenia & 32 & $43 \%$ \\
\hline Osteoporosis & 15 & $30 \%$ \\
\hline
\end{tabular}

Sumber Tabel: Data Primer dan Data Sekunder 2017

\section{Hubungan Antara Aktifitas Fisik dengan Kekuatan Tulang Pasien Menopause}

Analisis bivariat dalam penelitian dilakukan menggunakan uji Chi-Square. Hasil analisis bivariat aktifitas fisik dengan kekuatan tulang pada pasien menopause didapatkan nilai p yaitu 0,004 $(\mathrm{p}<0,005)$, yang berarti terdapat hubungan antara aktifitas fisik dengan kekuatan tulang pada pasien menopause. Nilai $\mathrm{p}$ dapat dilihat pada Tabel 2.

Tabel 2. Hubungan Aktifitas Fisik dengan Kekuatan Tulang pada Pasien Menopause di Rumah Sakit Olahraga Nasional Kemenpora tahun 2017

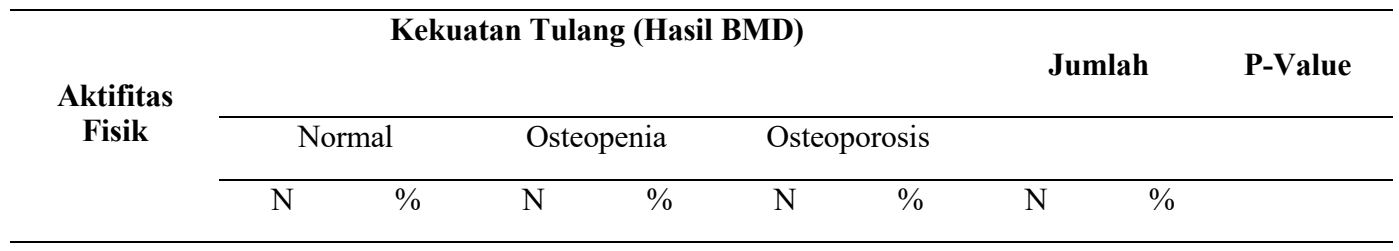




\begin{tabular}{|c|c|c|c|c|c|c|c|c|c|}
\hline Ringan & 10 & 37 & 20 & 63 & 3 & 20 & 33 & 45 & \multirow{4}{*}{0,004} \\
\hline Sedang & 14 & 52 & 6 & 19 & 5 & 33 & 25 & 34 & \\
\hline Berat & 3 & 16 & 6 & 18 & 7 & 47 & 16 & 22 & \\
\hline Jumlah & 27 & 100 & 32 & 100 & 15 & 100 & 74 & 100 & \\
\hline
\end{tabular}

\section{Pembahasan}

Berdasarkan hasil penelitian usia menunjukkan bahwa sebagian besar responden yang berusia 51-60 tahun yaitu sebanyak 39 responden (53\%). Usia wanita memasuki menopause adalah 51 tahun (Fox-Spencer 2007, hlm. 18). Sebagian besar wanita mulai mengalami gejala menopause pada usia 40-an dan puncaknya tercapai pada usia 50 tahun. Pada usia menopause terjadi penurunan hormon estrogen sehingga menyebabkan osteoblast (pembentukan massa tulang) pun akan terhambat dan kadar mineral tulang akan berkurang (Sherwood, 2011).

Berdasarkan hasil penelitian aktifitas fisik menujukkan bahwa sebagian besar responden memiliki aktifitas fisik ringan yaitu sebanyak 33 responden (45\%). Kurangnya aktifitas fisik merupakan faktor risiko untuk terjadinya penyakit kronis diantaranya osteoporosis (WHO, 2010). Peluang terjadinya osteoporosis 2 kali lebih besar pada wanita usia lanjut yang jarang melakukan aktifitas fisik daripada yang sering melakukan aktifitas fisik (Lane, 2001). Menurut Ganong (2008), seseorang yang malas bergerak atau berolahraga akan terhambat proses osteoblasnya (Ganong, 2008).

Berdasarkan hasil penelitian kekuatan tulang menujukkan bahwa sebagian besar responden memiliki kekuatan tulang yang diukur dengan tingkat kepadatan tulang yang di nilai dari hasil pemeriksaan Bone Mass Densitometry (BMD) yaitu osteopenia sebanyak 32 responden (43\%) yang menggunakan teknologi DEXA (Dual-energy X-Ray Absorptiometry).

Berdasarkan hasil penelitian bahwa pasien aktifitas fisik ringan dengan proporsi terbesar sebanyak 63\% yang mengalami osteopenia, kemudian pasien aktifitas fisik sedang dengan proporsi sebanyak $52 \%$ normal, dan pasien aktifitas fisik berat dengan proporsi sebanyak $47 \%$ yang mengalami osteoporosis. Berdasarkan hasil analisis uji bivariat dengan Chi-Square didapatkan $p$-value sebesar $0,004(\mathrm{p}<0,005)$ menandakan bahwa terdapat hubungan antara aktifitas fisik dengan kekuatan tulang pada pasien menopause.

Kurangnya aktifitas fisik dan wanita menopause menyebabkan penurunan kepadatan tulang dikarenakan pada wanita menopause terjadi penurunan produksi hormon estrogen yang menyebabkan penurunan aktifitas osteoblas sehingga terjadi penurunan kepadatan tulang (Sherwood, 2011). Peluang terjadinya osteoporosis 2 kali lebih besar pada wanita usia lanjut yang jarang melakukan aktifitas fisik daripada yang sering melakukan aktifitas fisik (Lane, 2001). Aktifitas fisik yang kurang merupakan faktor risiko untuk terjadinya penyakit kronis diantaranya osteoporosis (WHO, 2010). Hasil penelitian ini sejalan dengan dengan penelitian Kosnayani (2007), yang menyatakan bahwa terdapat hubungan antara aktifitas fisik dengan kepadatan tulang pada wanita pasca menopause $(\mathrm{p}=0,000)$.

\section{KESIMPULAN DAN SARAN}


Kesimpulan dari penelitian ini bahwa terdapat hubungan antara aktifitas fisik dengan kekuatan tulang pada pasien menopause di Poli Orthopedi RSON Kemenpora tahun 2017 dengan P-Value pada Uji Chi Square didapatkan bahwa P-Value sebesar 0,004 (p<0,005).

\section{REFERENSI}

Departemen Kesehatan, Pemerintah Indonesia 2015, Data dan Kondisi Penyakit Osteoporosis di Indonesia, Pusat Data dan Informasi, diakses tanggal 09 Juli 2017.

http://www.depkes.go.id/resources/download/pusdatin/infodatin/infodatin-osteoporosis.pdf

Fox-Spencer, R \& Brown 2007, Simple guides Osteoporosis, Erlangga, Jakarta.

Ganong, WF 2008, Buku Ajar Fisiologi Kedokteran, EGC, Jakarta.

International Osteoporosis Foundation 2009, The Asian Audit Epidemiology, Cost and Burden of Osteoporosis in Asia 2009, diakses tanggal 6 Juli 2017. https://www.iofbonehealth.org/sites/default/files/PDFs/Audit\%20Asia/Asian_regional_aud it_2009.pdf.

Lane 2001, The Osteoporosis Book a Guide for Patients and Their Famillies, Oxford University Press, New York.

Prihartini, S 2010, Faktor Determinan Risiko Osteoporosis di Tiga Provinsi Indonesia, Vol. 20, No. 2, hlm 91-99, diakses tanggal 7 juli 2017.

http://ejournal.litbang.depkes.go.id/index.php/MPK/article/view/787.

Sherwood, L 2011, Human Physiology: from Cells to Systems, EGC, Jakarta.

Sugiyono 2009, Metode Penelitian Kuantitatif, Kualitatif dan R\&D, Alfabeta, Bandung.

Swarjana 2006, Statistik Kesehatan. Penerbit Andi, Yogyakarta.

World Health Organization 2003, Prevention and Management of Osteoporosis: Report Of A WHO Scientific Group, Geneva, diakses pada tanggal 10 Juli 2017.

http://apps.who.int/iris/bitstream/10665/42841/1/WHO_TRS_921.pdf.

World Health Organization 2010, Global Recommendation on Physical Activity for Health 1864 years, Geneva, diakses pada tanggal 14 Juli 2017.

http://www.who.int/dietphysicalactivity/factsheet_recommendations/en/.

World Health Organization 2015, Global Physical Activity Questionnaire (GPAQ) Analysis Guide, Geneva, diakses pada tanggal 14 Juli 2017.

http://www.who.int/chp/steps/resources/GPAQ_Analysis_Guide.pdf. 